\title{
Germination of parsley seeds influenced by mericarps color and internal morphology
}

\author{
Sueyde F de Oliveira; Denis S da Costa; Simone da C Mello; Ana Dionisia da LC Novembre; Francisco G \\ Gomes-Junior
}

USP-ESALQ, Depto. Prod. Vegetal, C. Postal 09, 13418-900 Piracicaba-SP; sueydefo@yahoo.com.br; denis.esalq@gmail.com; scmello@ usp.br; adlcnove@usp.br; francisco1@usp.br

\begin{abstract}
The objective of the present study was to establish a relationship between mericarps color and internal morphology of parsley with the germination, using sorting by coloration and the X-ray test. The completely randomized design was used, with four replications per treatment. The treatments were constituted of four lots (A, B, C and D) and three mericarps colors (green, yellow and black) in $4 \times 3$ factorial experiment. The mericarps were exposed to X-ray test $(60 \mathrm{~s} ; 20 \mathrm{kV})$, being used the digital equipment Faxitron X-ray, model MX-20 DC12 and then, the irradiated mericarps were submitted to the germination test. The yellow mericarps showed higher germination and speed germination index. The green mericarps showed deformations and impaired formation of embryo, while black and yellow mericarps showed up without deformation and with a well-formed embryo. We concluded that there is a relationship between parsley seed germination and mericarps color. Poorly formed embryos and misshapened seed coats are related to green mericarps.
\end{abstract}

Keywords: Petroselinum crispum, X-ray, seed analysis, sorting by coloration.

\section{RESUMO}

Germinação de sementes de salsa em função da coloração do carpídio e da morfologia interna

O trabalho teve o objetivo de relacionar a coloração do carpídio e a morfologia interna de sementes de salsa com a germinação, por meio da classificação visual por coloração e do teste de raios X. O delineamento experimental utilizado foi inteiramente casualizado, com quatro repetições por tratamento, constituídos de quatro lotes (A, B, C e D) e três colorações dos carpídios (verde, amarela e preta) em esquema fatorial $4 \times 3$. As sementes foram radiografadas $(60 \mathrm{~s}$; $20 \mathrm{kV}$ ), utilizando o equipamento digital Faxitron X-ray, modelo MX-20 DC12 e, em seguida, foram submetidas ao teste de germinação. Verificou-se que os frutos de coloração amarela foram os que apresentaram as maiores taxas de germinação e índice de velocidade de germinação (IVG). Os frutos com carpídio de coloração verde apresentaram deformações e má formação do embrião, enquanto os frutos de coloração amarela e preta apresentaram-se sem deformações e com o embrião bem formado. Pode-se concluir que há relação entre a germinação e a coloração dos carpídios das sementes de salsa. Embriões mal formados e tegumentos deformados estão relacionados aos carpídios de coloração verde.

Palavras-chave: Petroselinum crispum, raios X, análise de sementes, classificação por cor.

(Recebido para publicação em 3 de maio de 2012; aceito em 18 de março de 2013) (Received on May 3, 2012; accepted on March 18, 2013)

$\mathrm{P}$ arsley (Petroselinum crispum) is commercialized either fresh or dried, alone or with chives (Allium schoenoprasum), forming the seasoning called "green seasoning" (cheiro verde) (Heredia-Zarate et al., 2003). This specie is cultivated mainly by small farmers who send their production in natura to market or industry.

One of the limiting factors for successful parsley cropping has been the difficulty in obtaining seeds that permit fast establishment with an ideal and uniform population, in other words, vigorous plants. This is due to the fact that the seeds are derived from inflorescences composed of sequentially formed umbels, that produce seeds with different degrees of maturity (Hawtuokn et al., 1962; Gray \& Steckel, 1983). One of the characteristics related to seed maturation of parsley is the mericarps color, parsley fruit, commonly treated as seed-unit (Brasil, 2009a) because, during this physiological process, the chlorophyll is degraded, soluble sugars are synthesized and soluble proteins modified (Adams et al., 1983; Steckel et al., 1989; Ward et al., 1992, 1995), altering the mericarps color.

Even when the harvest is divided up the seed maturity varies in each umbel so that germination is uneven (Gray \& Steckel, 1983; Pill \& Kilian, 2000).
Thus, seed emergence in the field takes up to four weeks or more, depending on the climatic conditions, soil management and irrigation. Therefore it is viable to use techniques that standardize the lots, accelerate germination and identify problems related to the seed, such as improving beneficiation, priming and image analysis (Nascimento, 2009; Rodrigues et al., 2009).

Image analysis represented by the $\mathrm{X}$-ray test is a promising technique due to the possibility of adding some new and essential information for seed lot quality control (Cícero \& Banzatto-Junior, 2003). X-ray images show the seed parts, identify the degree 
of development and other physical alterations (ISTA, 1995). This test has been used to study seed internal morphology, such as in the pumpkin (Cucurbita moschata) (Carvalho et al., 2009), pepper (Capsicum annuum cv. Sigaretta biondo) (Dell'Aquila, 2007) and tomato (Solanum lycopersicum) (Liu et al., 1993).

The objective of the present study was to establish a relationship between mericarps color and internal morphology of parsley with the germination, using sorting by coloration and the X-ray test.

\section{MATERIAL AND METHODS}

The research was carried out in a laboratory of the "Luiz de Queiroz" Agriculture College, University of São Paulo, in Piracicaba, São Paulo state, Brazil. Parsley mericarps, cv. Lisa Preferida were used, represented by four commercial lots.

Prior to defining the treatments, the lots were characterized by determining moisture content and the germination test, that supplied values of first germination count, germination and germination speed index (GSI). The moisture content was established by the oven method at $105 \pm 3^{\circ} \mathrm{C}$ for 24 hours, using $0.5 \mathrm{~g}$ seed samples for each lot (Brasil, 2009b). For the germination test, 50 seeds were sowed on blotting paper in plastic boxes $(11 \times 11 \times 3.5 \mathrm{~cm})$ and kept in a germinator at $20^{\circ} \mathrm{C} / 30^{\circ} \mathrm{C}$ alternating temperature. The assess was realized in 10 (first germination count) and 20 days after sowing (germination). The results were expressed in percentage of normal seedlings (whole numbers) (Brasil 2009b). After the first (10 days) and the second (28 days) germination count, the germination speed index (GSI) was calculated according to Maguire (1962).

After characterizing the lots, the parsley mericarps were separated by hand and visually by the mericarps color (Figure 1) to start the treatments, that consisted of three mericarps color (green, yellow and black) in four parsley mericarps lots (A, B, C and D) in $4 \times 3$ factorial experiment in a completely randomized design (CRD) with four replications.
The mericarps were submitted to the $\mathrm{X}$-ray test with four replications of 50 seeds for each mericarps color. For this, they were fixed with transparent doublesided adhesive tape on a $1 \mathrm{~mm}$ thick plastic plate and numbered according to their position for identification. The mericarps were placed inside a digital Faxitron X-ray machine, model MX-20 DC12, attached to a computer, placed at $19.1 \mathrm{~cm}$ from the X-ray emission source and exposed during 60 seconds using 20 $\mathrm{kV}$ of voltage.

The radiographed seeds were then submitted to the germination test, and the values obtained were first germination count, germination and germination speed index, as carried out for the lots characterization. To relate the morphological characteristics with the germination percentage and seedling development, the mericarps were photographed at the first germination count.

Data were submitted to analysis of variance by $\mathrm{F}$ test and, when the F value was significant at $5 \%$ probability $(\mathrm{p}<0.05)$, the means were compared by Tukey test (5\%).

\section{RESULTS AND DISCUSSION}

There was no significant difference in mericarps lots of parsley for water content, first germination count, germination and germination speed index, in the assessment carried out before separating according to the mericarps color (Table 1). Four mericarps lots of parsley presented moisture contents approximately $6.4 \%$; these data are essential for the discussions of the study because homogeneous water content in the lots allows inference that the results obtained were due to the effects of the treatments and not to factors intrinsic to the seeds. Also, the four mericarps lots of parsley presented $62-63 \%$ germination, values lower than the minimum recommended for certified seed commercialization $(80 \%)$. The mericarps lots of parsley did not differ for vigor, assessed by the first germination count and germination speed index.

After sorting by mericarps color and repeating the initial tests, significant differences were observed in all the lots, regarding the seed physiological potential with green, yellow and black mericarps (Table 2).

For the first germination count, the mericarps with yellow color showed higher normal plants values, followed by those with black and green color, in all the lots (Table 2). This indicated that the mericarps yellow had higher vigor than the other color, because the first germination count can be considered a vigor test (Nakagawa, 1999).

Azevedo et al. (2010) assessed the influence of the seed coat color on production and physiological quality of fennel seeds (Foeniculum vulgare) and reported higher vigor in the seeds with brown rather than green seed coat.

For color comparison, there were significant difference for the first germination count and germination speed index. Within yellow mericarps the values were higher for the lots $C$ and $\mathrm{D}$ and within black mericarps the lots $\mathrm{B}$ and $\mathrm{C}$ were higher than $\mathrm{A}$ and $\mathrm{D}$ lots (Table 2). This fact indicated that the

Table 1. Characterization of mericarps lots of parsley through moisture content, first germination count, germination and germination speed index (GSI) [caracterização dos lotes de sementes de salsa por meio da quantificação do teor de água e dos testes de primeira contagem, germinação e índice de velocidade de germinação (GSI)]. Piracicaba, ESALQ, 2010.

\begin{tabular}{lcccc}
\hline Lots & $\begin{array}{c}\text { Moisture } \\
\text { content }(\%)\end{array}$ & $\begin{array}{c}\text { First germination } \\
\text { count }^{\text {N.S. }}(\%)\end{array}$ & $\begin{array}{c}\text { Germination } \\
\text { N.S. }(\%)\end{array}$ & GSI $^{\text {N.S. }}$ \\
\hline A & 6.3 & 51 & 63 & 3.7 \\
B & 6.5 & 55 & 62 & 3.9 \\
C & 6.5 & 56 & 62 & 3.9 \\
D & 6.1 & 54 & 62 & 3.8 \\
\hline CV (\%) & - & 5.7 & 7.4 & 5.1 \\
\hline
\end{tabular}

N.S. Non significant at $5 \%$ of probability by $\mathrm{F}$ test (não significativo, $5 \%$ pelo teste $\mathrm{F}$ ). 


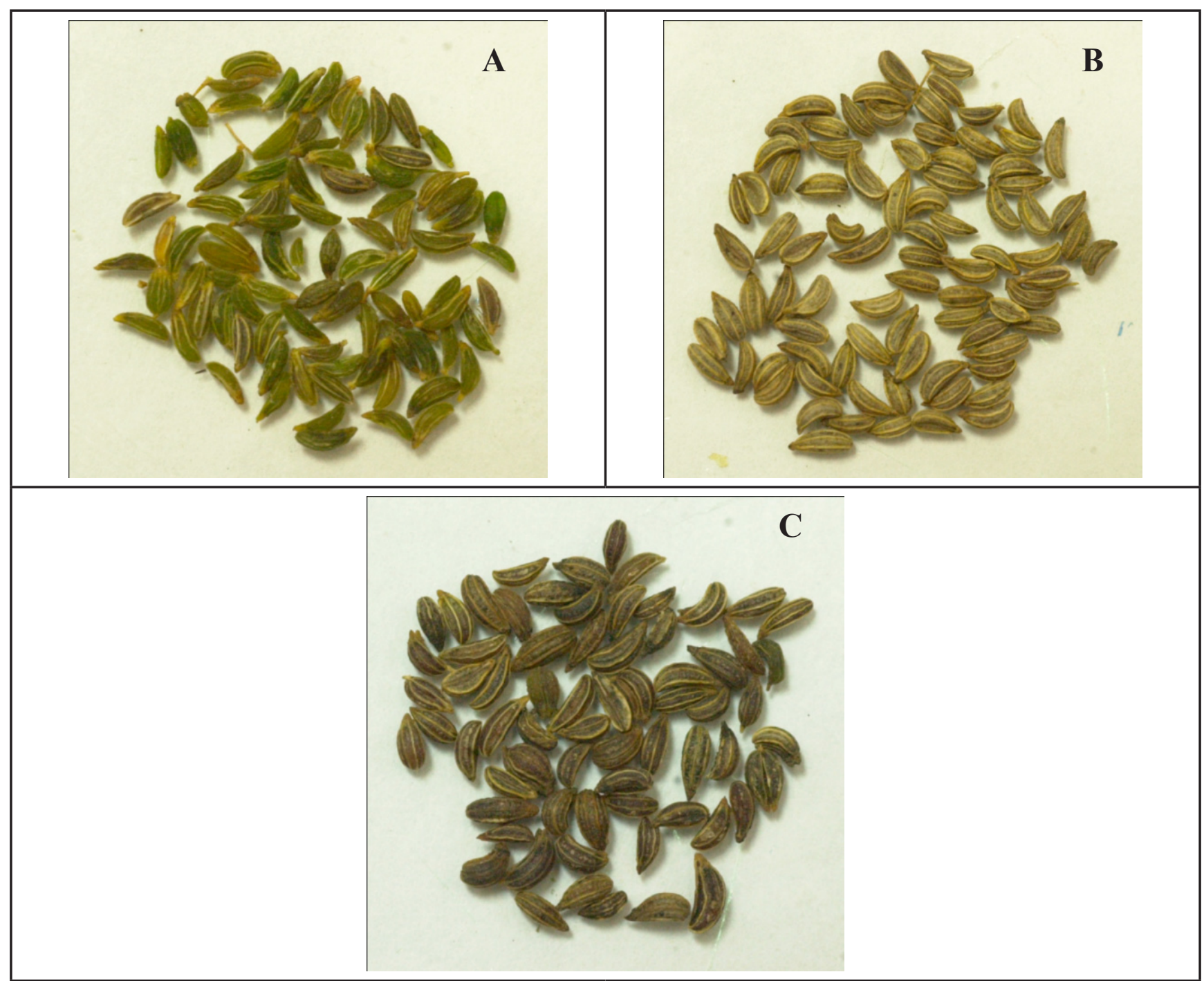

Figure 1. Sorting in three mericarps color categories: a) green mericarps; b) yellow mericarps; c) black mericarps (classificação em três categorias quanto à coloração das sementes de salsa: a) sementes verdes; b) sementes amarelas; c) sementes pretas). Piracicaba, ESALQ, 2010.

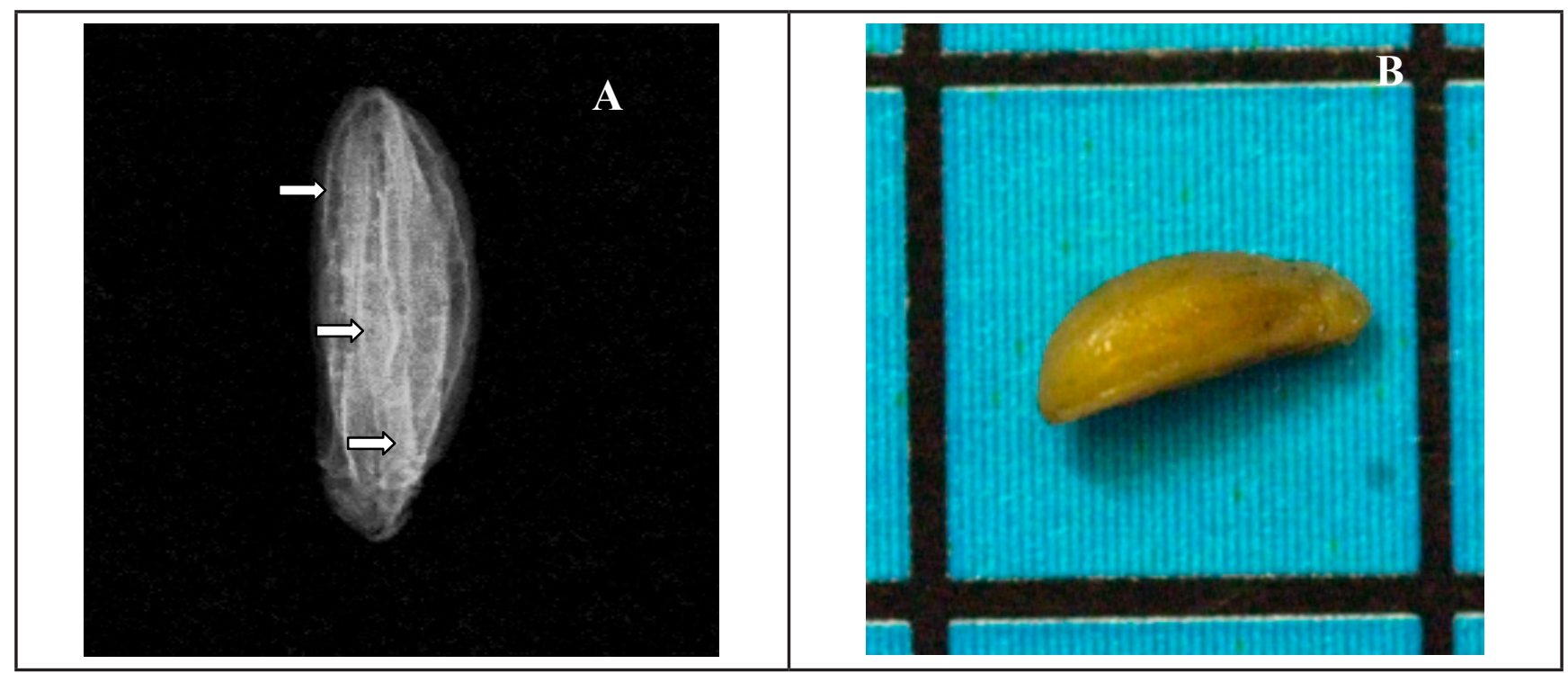

Figure 2. a) Radiography of parsley mericarp with green color showing the deformations in the embryo and coat; b) Mericarp not germinated (a) radiografia de semente de salsa com coloração verde, mostrando as deformações no embrião e tegumento; b) semente não germinada). Piracicaba, ESALQ, 2010. 
Table 2. First germination count, germination and germination speed index (GSI) of four parsley mericarps lots sorting by coloration (primeira contagem de germinação, germinação e índice de velocidade de germinação (GSI) de quatro lotes de sementes de salsa separadas por cor. Piracicaba, ESALQ, 2010.

\begin{tabular}{|c|c|c|c|c|c|c|c|c|c|}
\hline \multirow{2}{*}{ Lots } & \multicolumn{3}{|c|}{ First germination count $(\%) *$} & \multicolumn{3}{|c|}{ Germination $(\%) *$} & \multicolumn{3}{|c|}{ GSI* } \\
\hline & Green & Yellow & Black & Green & Yellow & Black & Green & Yellow & Black \\
\hline A & $7 \mathrm{aC}$ & $46 \mathrm{bA}$ & $29 \mathrm{bB}$ & $16 \mathrm{aC}$ & $88 \mathrm{aA}$ & $66 \mathrm{aB}$ & $0.6 \mathrm{aC}$ & $3.9 \mathrm{bA}$ & $2.6 \mathrm{bB}$ \\
\hline $\mathrm{B}$ & $4 \mathrm{aC}$ & $51 \mathrm{bA}$ & $42 \mathrm{aB}$ & $15 \mathrm{aC}$ & $80 \mathrm{aA}$ & $64 \mathrm{aB}$ & $0.4 \mathrm{aC}$ & $4.0 \mathrm{bA}$ & $3.2 \mathrm{aB}$ \\
\hline $\mathrm{C}$ & $3 \mathrm{aC}$ & $62 \mathrm{aA}$ & $45 \mathrm{aB}$ & $14 \mathrm{aC}$ & $88 \mathrm{aA}$ & $67 \mathrm{aB}$ & $0.4 \mathrm{aC}$ & $4.6 \mathrm{aA}$ & $3.4 \mathrm{aB}$ \\
\hline $\mathrm{D}$ & $6 \mathrm{aC}$ & $61 \mathrm{aA}$ & $24 \mathrm{bB}$ & $18 \mathrm{aC}$ & $82 \mathrm{aA}$ & $65 \mathrm{aB}$ & $0.6 \mathrm{aC}$ & $4.5 \mathrm{aA}$ & $2.4 \mathrm{bB}$ \\
\hline $\mathrm{CV}(\%)$ & & 10.7 & & & 8.1 & & & 7.4 & \\
\hline
\end{tabular}

*Same capital letters in the row and small letters in the column did not differ from each other by Tukey’s test (5\%) [Letras iguais maiúsculas nas linhas e minúsculas nas colunas não diferem entre si a 5\% de probabilidade pelo teste de Tukey].

mericarps color proposed for separation can highlight the physiological potential of the seeds and may be more evident when the lots are more uneven.

For lots comparison, germination was higher for yellow mericarps, followed by the black and green mericarps. Sorting by coloration showed more homogeneous germination for yellow mericarps and was equal or higher than $80 \%$, that is the minimum standard for commercialization (Table 2). This was not observed in lots before the sorting by coloration (Table 1 ) and for the green and black mericarps (Table 2). The low germination percentage observed in green mericarps may be because the mericarps were immature and their membrane system may not have been completely formed, causing the release of exudates including sugars and thus favoring fungi development (MarcosFilho, 2005), as observed visually in the present study (data not shown). The black mericarps may have been formed at the begin of bloom and, thus, remained vulnerable to the production environment for longer, being more subjected to the deterioration process. It is pointed out that parsley is a species that bloom unevenly and it is common to find seeds that are immature and deteriorated in their lots.

Similar to parsley, Azevedo et al. (2010) reported a higher germination rate for brown seeds of fennel (Foeniculum vulgare) than green seeds. The same was reported by Jalink et al. (1998) and Perleberg et al.(2001), who studied the relationship between chlorophyll content in seed coat and the physiological quality of cauliflower and carrot seeds, respectively, and observed that seeds with lower chlorophyll content had higher germination values. Freitas et al. (2007) assessed cabbage seed maturity and quality and reported that those with dark green siliques had lower germination capacity and uneven seedling development compared to the beige seeds, and the percentage of normal seedlings and beige seeds did not differ from the purple seeds.

The germination speed index (Table 2) differed significantly among the mericarps lots of parsley sorting by coloration, similar to the results observed in first germination count (Table 2). It was observed that the values obtained for the germination speed index varied with the mericarps color, and were higher for yellow than black and green.

It was observed that was possible to improve the quality of mericarps lots of parsley sorting by color because there was a relationship between germination and mericarps color. Furthermore, the X-ray test showed that the green mericarps had poorly formed embryo and misshapen coat (Figure 2) while those with yellow and black mericarps were not misshapen and the embryos were well formed.

It can be inferred from these results that there is a relationship between the seed color and its internal morphology. Green seeds come from early harvest, that is, they have not reached the point of physiological maturity that represents the moment of maximum seed quality (Nascimento, 2009). The influence of internal morphology on seed physiological quality has also been observed in some studies, including that by Carvalho et al. (2009), who reported a relationship between the internal morphology and seeds quality by the X-ray test. Nakada et al. (2011) assessed the maturity stage of cucumber seeds by the X-ray test and concluded that the harvest period of the cucumber seed was directly related to germination. Similarly, Gagliardi (2009) observed the efficiency of X-rays in detecting anomalies in sweet pepper seeds that allowed improvement in the quality of the lot by discarding the badly shaped seeds.

Thus it was concluded that there is a relationship between parsley seed germination and mericarps color. Poorly formed embryos and misshapen seed coats are related to green mericarps.

\section{REFERENCES}

ADAMS CA; FJERSTAD MC; RINNE RW. 1983. Characteristics of soybean seed maturation: necessity for slow dehydration. Crop Science 23: 265-267.

AZEVEDO CF; BRUNO RLA; REGO ER; QUIRINO ZGM. 2010. Influência da coloração do tegumento na produção e na qualidade fisiológica de sementes de ervadoce. Horticultura Brasileira 28: 4173-4180.

BRASIL. Ministério da Agricultura Pecuária e Abastecimento. 2009a. Glossário ilustrado de morfologia. Ministério da Agricultura Pecuária e Abastecimento. Secretaria da Defesa Agropecuária. Brasília, DF: MAPA/ ACS. $406 \mathrm{p}$.

BRASIL. Ministério da Agricultura, Pecuária e Abastecimento. 2009b. Regras para análise de sementes. Ministério da Agricultura, Pecuária e Abastecimento. Secretaria de Defesa Agropecuária. Brasília, DF: Mapa/ACS. 395p. 
CARVALHO MLM; SILVACD; OLIVEIRALM; SILVA DG; CALDEIRA CM. 2009. Teste de raios x na avaliação da qualidade de sementes de abóbora. Revista Brasileira de Sementes 31: 221-227.

CICERO SM; BANZATTO JUNIOR HL. 2003. Avaliação do relacionamento entre danos mecânicos e vigor, em sementes de milho, por meio da análise de imagens. Revista Brasileira de Sementes 25: 29-36.

DELL'AQUILAA. 2007. Pepper seed germination assessed by combined X-radiography and computer-aided imaging analysis. Biologia Plantarum 51: 777-781.

FREITAS RA; NASCIMENTO WM; COIMBRA KG. 2007. Maturação e qualidade de sementes de repolho de verão sob condições tropicais. Horticultura Brasileira 25: 586-589.

GAGLIARDI B. 2009. Procedimentos para avaliação do potencial fisiológico de sementes de pimentão e relações com a emergência de plântulas. Piracicaba: USP-ESALQ. 75p. (Tese mestrado).

GRAY D; STECKEL JRA. 1983. Some effects of umbel order and harvest date on carrot seed variability and seedling performance. Journal Horticulture Science 58: 73-82.

HAWTUOKN LR; TOOLE EH; TOOLE VK. 1962. Yield and viability of carrot seeds as affected by position of umbel and time of harvest. Journal Horticultural Science 80: 401-407.

HEREDIA-ZARATE NA; VIEIRA MC; WEISMANN M; LOURENÇÃO ALF. 2003.
Produção e renda bruta de cebolinha e de salsa em cultivo solteiro e consorciado. Horticultura Brasileira 21: 574-577.

INTERNATIONAL SEED TESTING ASSOCIATION. 1995. International rules for testing seed. Seed Science and Technology 21: 363 .

JALINK H; FRANDAS A; SCHOOR R; BINO JB. 1998. Chlorophyll fluorescence of the testa of Brassica oleracea seeds as an indicator of seed maturity and seed quality. Scientia Agricola 55: 88-93.

LIU Y; BURG WJ; AARTSE JW; ZWOL RA; JALINK H; BINO RJ. 1993. X-ray studies on changes in embryo and endosperm morphology during priming and imbibition of tomato seeds. Seed Science Research 3: 171-178.

MAGUIRE JB. 1962. Speed of germinationaid in selection and evaluation for seedling emergence vigor. Crop Science 2: 176-177.

MARCOS-FILHO J. 2005. Fisiologia de sementes de plantas cultivadas. Piracicaba: FEALQ. 495p.

NAKADA PG; OLIVEIRA JA; MELO LC; GOMES LAA; PINHO EVR. 2011. Desempenho fisiológico e bioquímico de sementes de pepino nos diferentes estádios de maturação. Revista Brasileira de Sementes 33: 113-122.

NAKAGAWA J. 1999. Testes de vigor baseados na avaliação das plântulas. In: KRZYZANOWSKI FC; VIEIRA RD; FRANÇA-NETO JB. (ed) Vigor de sementes: conceitos e testes. Londrina:
ABRATES, p. 2.1-2.21.

NASCIMENTO WM. (org) 2009. Tecnologia de Sementes de Hortaliças. EMBRAPA Hortaliças. $1^{\mathrm{a}}$. ed. Brasília-DF, 432p.

PERLEBERG CS; CÍCERO SM; JALINK H; HEIJDEN G. 2001. Uso de fluorescência de clorofila para avaliar a qualidade fisiológica de sementes de cenoura. Informativo Abrates, 11: 293.

PILL WG; KILIAN EA. 2000. Germination and emergence of parsley in response to osmotic or matric seed priming and treatment with gibberellin. HortScience 35: 907-909.

RODRIGUES APAC; LAURA VA; CHERMOUTH KS; GADUM J. 2009. Osmocondicionamento de sementes de salsa (Petroselinum sativum Hoffm.) em diferentes potenciais hídricos. Ciência e Agrotecnologia 33: 1288-1294.

STECKEL JRA; GRAY D; ROWSE HR. 1989. Relationships between indices of seed maturity and carrot seed quality. Annals of Applied Biology 114: 177-183.

WARD K; SCARTH R; DAUN J; McVETTY PBE. 1992. Effects of genotype and environment on seed chlorophyll degradation during ripening in four cultivars of oilseed rape (Brassica napus). Canadian Journal of Plant Science 72: 643-649.

WARD K; SCARTH R; DAUN J; VESSEY JK. 1995. Chlorophyll degradation in summer oilseed rape and summer turnip rape during seed ripening. Canadian Journal of Plant Science 75: 413-420. 